1]SRST

(C) 2020 | International Journal of Scientific Research in Science and Technology

IJSRST | Volume 7 | Issue 3 | Print ISSN: 2395-6011 | Online ISSN: 2395-602X

DOI : https://doi.org/10.32628/IJSRST207336

\title{
Developing an Effective e-Learning Platform
}

Noora Yousef A Alomran, Amani Osama M Alameer, Maryam Sami K Alherz, Mohammed Fahed Tayfour, Muneerah Alshabanah, Daniah Alrajhi, Mutasem K. Alsmadi

Department of Management Information Systems, College of Applied Studies and Community Service, Imam Abdulrahman Bin Faisal University, Dammam, Saudi Arabia

\begin{abstract}
Modern institutions, corporations, schools and universities in developed countries believe that e-Learning is a way for educating larger number of students in less time and lesser amount of resources. This research aims to design and develop a web-based e-learning system to make the environment of e-learning more adaptive and intelligent for the learners. The main values of the proposed research are accessibility and interoperability that make learning applications and components share data more easily and communicate more effectively. The proposed work was developed and designed using ASP.Net, SQL, XML and the Unified Modeling Language (UML) programming languages.
\end{abstract}

Keywords : Student; E-Learning Platform and Unified Modeling Language (UML).

\section{INTRODUCTION}

The last years has been witness to important change across wide areas of our cultural, social and physical systems. Education has also must adapt change reflected in the constantly growing population of students, which occupy places on current or newly created courses covering a wide range of subjects. The consequences of these changes are increasing the ration of student/staff, lessening in contact hours of the student which, if traditional educational methods persist, will cause a diminishing quality in the offered learning experience [1-5].

E-Learning was described as using the telecommunication technology for delivering, supporting and enhancing learning and teaching $[1,2$, 6-8].

Basically, E-Learning is a web-based system which makes knowledge or information available for the learners or users and disregards geographic proximity or time restrictions, allows interactions between instructors and learners, or between learners themselves [1]. The online educational system development for a university seminar course or coop training was attributed to several causes:

- It is easier for many participants to more completely and successfully get the educational content.

- Reduced expenses and time waste of the students for traveling to the class location;

- Improved impression of the instructor/teacher and the institution which arranged the instruction;

- Accessible financial resources that make the effort and time financially valuable;

- It is a chance to join the modern trends and master new educational technologies.

- Assess the cost-effectiveness of investment into elearning. 


\section{RELATED WORKS}

"EDMODO" It is a free social platform that provides teachers and students with a safe environment for communication and cooperation, and the exchange of educational content and digital applications in addition to homework, grades and discussions $[9,10]$. It combines the features of Facebook and Blackboard Learning Management System, and uses Web 2.0 technology. The platform is currently used by more than 47 million members, teachers, students, school administrators, and parents. It deserves the title of the first and largest social learning network in the world.

"Blackboard" is an integrated e-learning management system, as it manages the educational process in a synchronous and asynchronous manner, and provides a safe learning environment, teachers provide their decisions and lectures through the addition of multimedia (text, pictures, audio, video, graphics), in which they meet Learners browse content as needed, and communicate with each other through multiple communication tools [11-13].

"Moodle" is a Learning Platform or course management system (CMS). The system is transforming the work of educational organizations from traditional to e-work, which is very similar to the BlackBoard e-learning system used in many universities around the world [11, 12]. Where the Moodle system can accelerate the educational process and ensure its quality significantly, which is easy to use either by the administration or the educational staff and even students who benefit from the system, and the educational organization can easily install it on its website and change the design to match the identity of the educational organization. This system may greatly benefit educational charities, such as the Quran memorization societies, all non-profit schools, institutes and universities, and others.

The technological revolution influenced everything [14-91]. Nowadays; the artificial intelligent (AI) algorithms were used extensively in solving many difficult problems, such as Healthcare Monitoring [54, 65], river flow forecasting [46, 92, 93], image segmentation [17, 35, 36, 51, 94-98], medical image analysis [37, 41, 99-101], patterns recognition and information retrieval $[24,30,32,39,40,45,50,102-$ 106] and nurse rostering problem [107]. Recently; a number of researchers used the AI algorithms in order to enhance and improve the LMS [108-112].

\section{METHODOLOGY}

The Unified Modeling Language (UML) is a graphical programming language used to visualize, specify, construct, and document a software-intensive system artifacts. UML offers a way to write a system's blueprints, with conceptual things such as system functions and business processes as well as concrete things such as reusable software components, database schemas, and programming language statements $[52,53,62,63,66,68,69,72,76,81,82,88$, 113-120].

\subsection{Use Case Diagram}

Use Case diagrams provide a very good overview of the entire system on a highly abstract level [113-116]. They describe functionality - services and activities to be performed - from the view of the user, and act as the interfaces to the environment. In the proposed application, the actors are the Admin, Manager, Teacher, Student and Visitor. Figure 1 shows the use case diagram for the proposed system. 


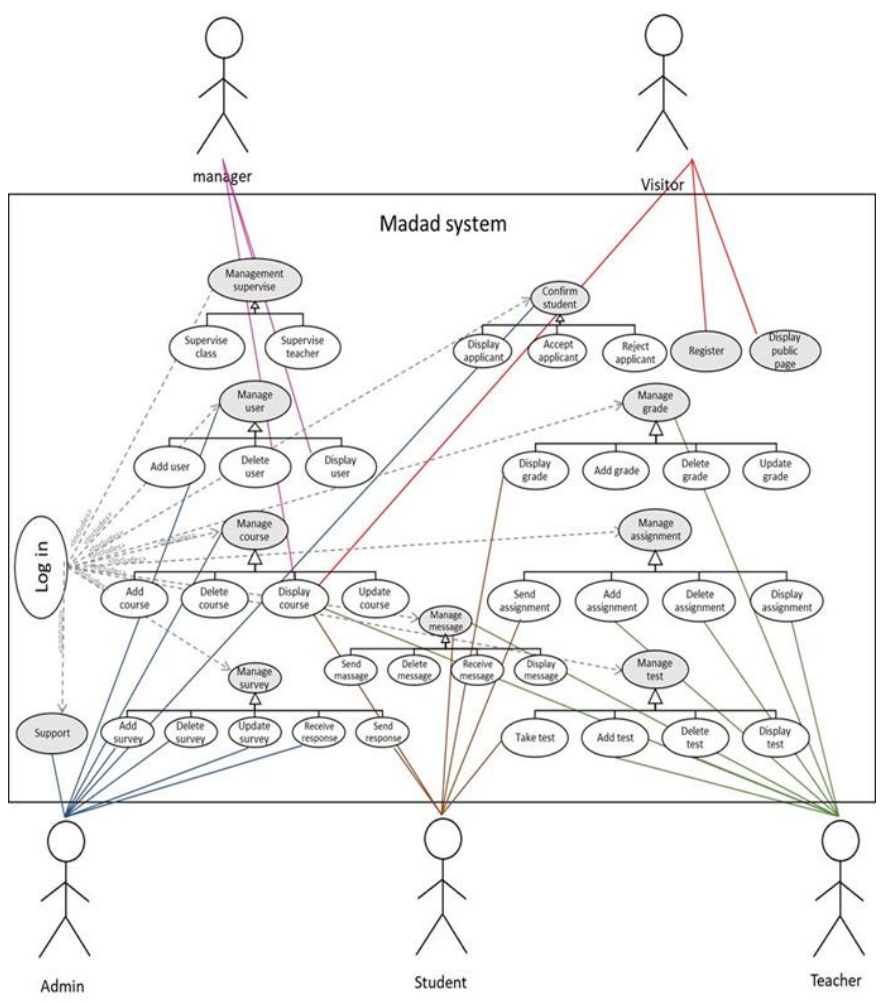

Figure 1: Use case diagram for the proposed system

\subsection{Context diagram}

A context diagram is a graphical natation of a system with single process to denote the entire system and does not define all the processes deliberately so as to prevent people getting get involved in complicated details at the very beginning [113-116]. Figure 2 represents the context diagram of the proposed system.

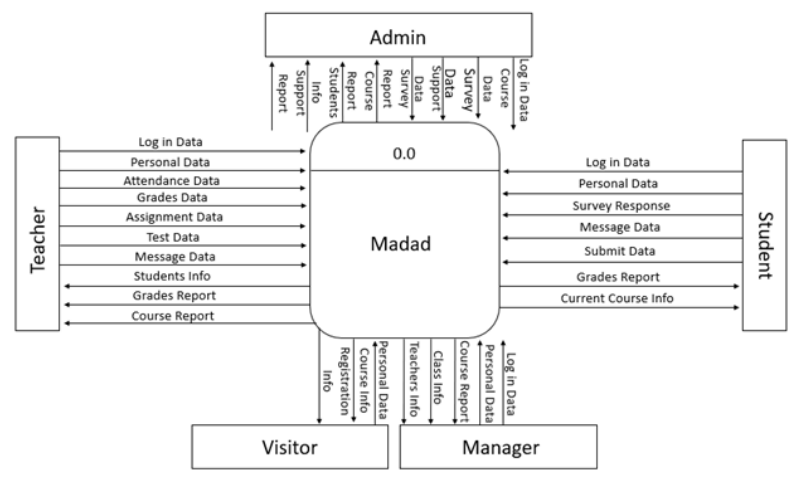

Figure 2: context diagram of the proposed system.

\subsection{Entity Relationship Diagram (ERD)}

An entity relationship diagram (ERD) demonstrates the relationships of entity sets in a database. In this context, the entity is an object which is component of data. An entity set is a group of entities that are similar, it can have attributes to describe its properties [113-116]. Figure 3 shows the ER diagram for the proposed system.

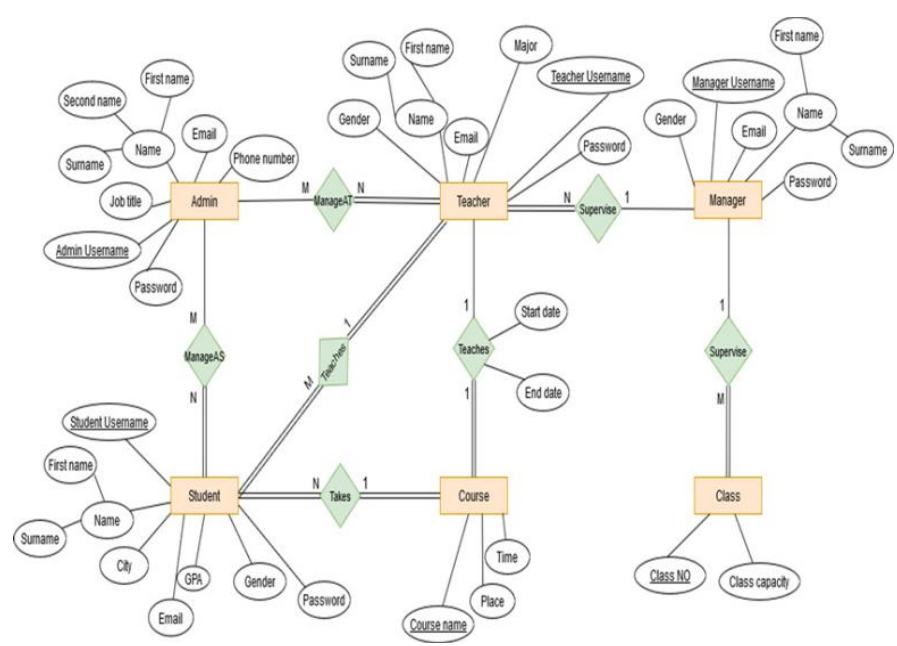

Figure 3: ER diagram for the proposed system.

\subsection{Database Testing and Construction}

Database testing is commonly done on all types of apps. It is important to consider using quality tools to test based on the necessity. There are different types of available tools for database testing. Most of them are commonly designed to perform set of tasks. To implement the database of the proposed system SQL 
was utilized. Tables 1 and 2 below are example of the created tables.

Table 1: Students table

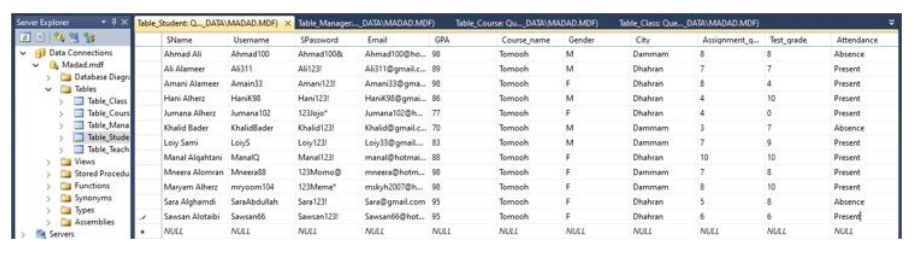

Table 2: Teachers table

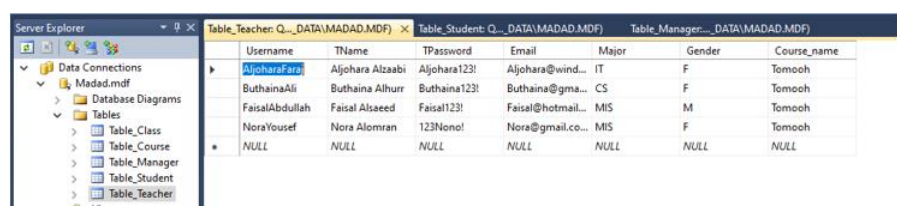

Table 3: Managers table

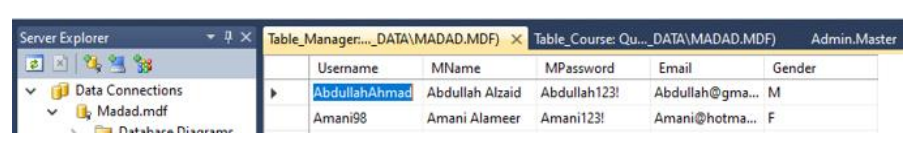

\subsection{Interface design}

User interface design denotes the design of visual user interfaces in computerized devices or software. It's the total design, the way of presenting information, and the way of users interaction with the website. The below figures are examples of the designed interfaces.

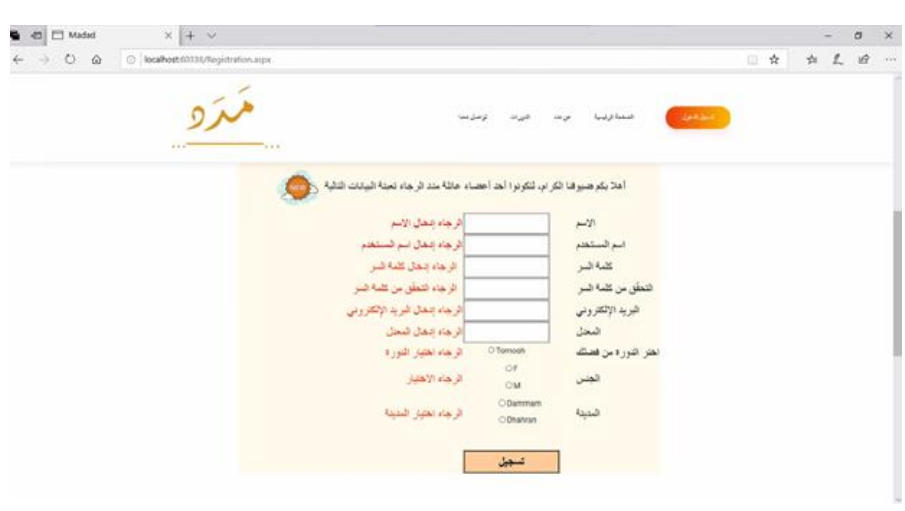

Figure 4: Registration page.

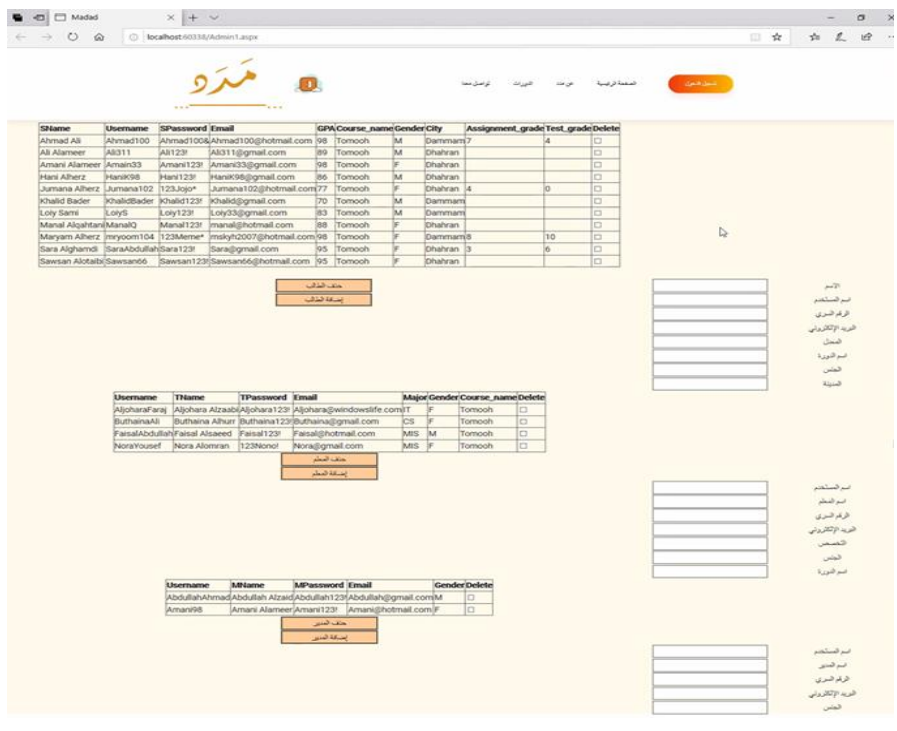

Figure 5: Supervisor page.

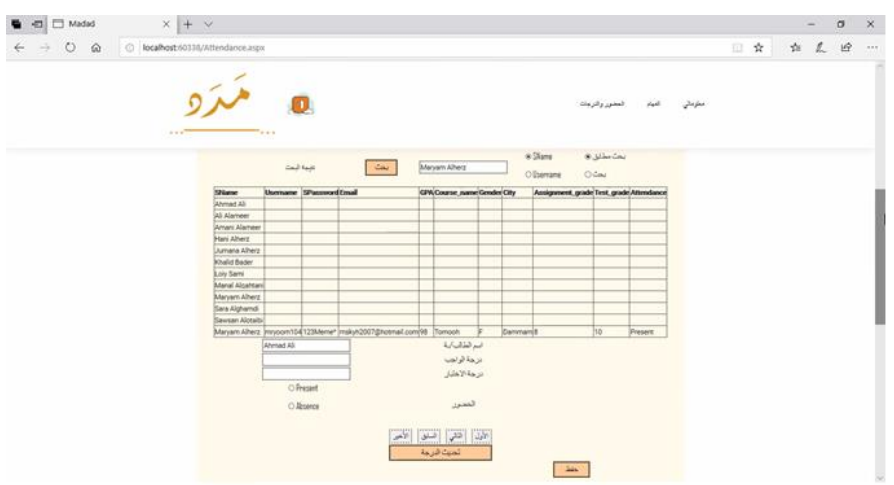

Figure 6: Attendance page.

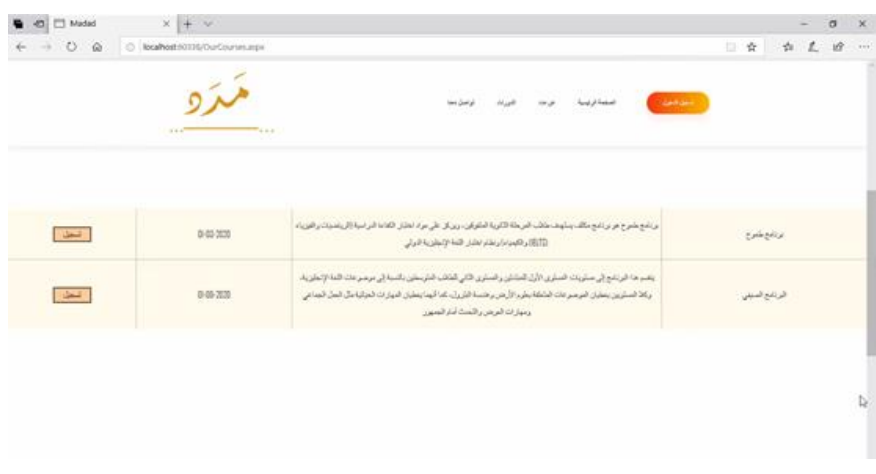

Figure 7: Training page.

\section{DISCUSSION}

To evaluate the system, we invited 20 students from the Imam Abdurrahman Bin Faisal University (IAU) 
at the College of Applied Studies and Community Service for using the proposed system. A brief description of the system interface and usage was illustrated to the students. after tested the system, the student answered a survey which consists of 10 items to measure the user satisfaction level (as shows in table 4). As can be interpreted from the result, the majority of users agree that the system is easy to use, beneficial and achieves the primary objective of the project.

Table 4: collected data results from the 20 students.

\begin{tabular}{|l|r|r|r|r|r|r|r|r|r|r|}
\hline & $\begin{array}{l}\text { Q } \\
1\end{array}$ & $\begin{array}{l}\text { Q } \\
2\end{array}$ & $\begin{array}{l}\text { Q } \\
3\end{array}$ & $\begin{array}{l}\text { Q } \\
4\end{array}$ & $\begin{array}{l}\text { Q } \\
5\end{array}$ & $\begin{array}{l}\text { Q } \\
6\end{array}$ & $\begin{array}{l}\text { Q } \\
7\end{array}$ & $\begin{array}{l}\text { Q } \\
8\end{array}$ & $\begin{array}{l}\text { Q } \\
9\end{array}$ & $\begin{array}{l}\text { Q1 } \\
0\end{array}$ \\
\hline $\begin{array}{l}\text { Strongl } \\
\text { y } \\
\text { disagre } \\
\text { e }\end{array}$ & & & & & & & & & & \\
\hline $\begin{array}{l}\text { Disagre } \\
\text { e }\end{array}$ & & & & & & & & & & \\
\hline $\begin{array}{l}\text { Neutral } \\
\text { Agree }\end{array}$ & 5 & 5 & 6 & 4 & 3 & 2 & 1 & 3 & 4 & 5 \\
\hline $\begin{array}{l}\text { Strongl } \\
\text { y agree }\end{array}$ & 9 & 6 & 7 & 9 & 11 & 10 & 8 & 14 & 4 & 4 \\
\hline
\end{tabular}

\section{v. CONCLUSION}

This research designed and developed a web-based elearning system to make the environment of elearning more adaptive and intelligent for the learners. The main values of the proposed research are accessibility and interoperability that make learning applications and components share data more easily and communicate more effectively. The proposed work was developed and designed using ASP.Net, SQL, XML and the Unified Modeling Language (UML) programming languages.

\section{REFERENCES}

[1]. Violante M G and Vezzetti E. Implementing a new approach for the design of an e-learning platform in engineering education. Computer Applications in Engineering Education, 2014, 22(4): 708-727.

[2]. Zhu Z. Design and implementation of webservices based E-learning system. In 2009 First International Workshop on Education Technology and Computer Science, pp. 233237.

[3]. Jung S and Huh J-H. An Efficient LMS Platform and Its Test Bed. Electronics, 2019, 8(2): 154.

[4]. Siddiqui S T, Alam S, Khan Z A and Gupta A. Cloud-Based E-Learning: using cloud computing platform for an effective E-Learning. Smart Innovations in Communication and Computational Sciences. Springer, 2019, pp. 335-346.

[5]. Ansari M H, Moradi $M$, NikRah $O$ and Kambakhsh K M. CodERS: a hybrid recommender system for an E-learning system. In 2016 2nd International Conference of Signal Processing and Intelligent Systems (ICSPIS), pp. 1-5.

[6]. Appalla P, Kuthadi V M and Marwala T. An efficient educational data mining approach to support e-learning. Wireless Networks, 2017, 23(4): 1011-1024.

[7]. Şerban G and Enescu F M. Dynamic Web for Efficient Educational Management. In 2019 11th International Conference on Electronics, Computers and Artificial Intelligence (ECAI), pp. 1-6.

[8]. Popescu P-S, Mihaescu C, Iordache D D and Pribeanu C. Usability evaluation of Tesys eLearning platform. In RoCHI, pp. 38-41.

[9]. Borg N, O'hara J and Hutter C. About Edmodo. Retrieved December, 2008, 3: 2013. 
[10]. Balasubramanian K, Jaykumar V and Fukey L N. A study on "Student preference towards the use of Edmodo as a learning platform to create responsible learning environment". ProcediaSocial and Behavioral Sciences, 2014, 144(1): 416-422.

[11]. Finogeev A, Kravets A, Deev M, Bershadsky A and Gamidullaeva L. Life-cycle management of educational programs and resources in a smart learning environment. Smart Learning Environments, 2018, 5(1): 9.

[12]. Krouska A, Troussas C and Virvou M. Comparing LMS and CMS platforms supporting social e-learning in higher education. In 2017 8th International Conference on Information, Intelligence, Systems \& Applications (IISA), pp. 1-6.

[13]. Holmes K A and Prieto-Rodriguez E. Student and Staff Perceptions of a Learning Management System for Blended Learning in Teacher Education. Australian Journal of Teacher Education, 2018, 43(3): 21-34.

[14]. Almarashdeh I and Alsmadi M K. How to make them use it? Citizens acceptance of $\mathrm{M}$ government. Applied Computing and Informatics.

[15]. Alsmadi M, Omar K, Noah S and Almarashdeh I. Fish recognition based on robust features extraction from size and shape measurements using neural network. Information Technology Journal, 2009, 10(5): 427-434.

[16]. Alsmadi M, Omar K B and Noah S A. Back propagation algorithm: the best algorithm among the multi-layer perceptron algorithm. International Journal of Computer Science and Network Security, 2009, 9(4): 378-383.

[17]. Alsmadi M k, Omar K B and Noah S A. Proposed method to decide the appropriate feature set for fish classification tasks using Artificial Neural Network and Decision Tree. IJCSNS 2009, 9(3): 297-301.
[18]. Alsmadi M K S, Omar K B, Noah S A and Almarashdah I. Fish recognition based on the combination between robust feature selection, image segmentation and geometrical parameter techniques using Artificial Neural Network and Decision Tree. arXiv preprint arXiv:0912.0986, 2009.

[19]. khalil Alsmadi M, Omar K B, Noah S A and Almarashdah I. Performance comparison of multi-layer perceptron (Back Propagation, Delta Rule and Perceptron) algorithms in neural networks. In 2009 IEEE International Advance Computing Conference, pp. 296-299.

[20]. Almarashdeh I A, Sahari N, Zin N A M and Alsmadi M. The Success Of Learning Management System Among Distance Learners In Malaysian Universities. Journal of Theoretical \& Applied Information Technology, 2010, 21(2).

[21]. Almrashdah I A, Sahari N, Zin N A H M and Alsmadi M. Instructors acceptance of distance learning management system. In Information Technology (ITSim), 2010 International Symposium in, pp. 1-6.

[22]. Almrashdah I A, Sahari N, Zin N A H M and Alsmadi M. Distance learners acceptance of learning management system. In Advanced Information Management and Service (IMS), 2010 6th International Conference on, pp. 304309.

[23]. Alsmadi M K, Omar K B and Noah S A. Fish recognition based on robust features extraction from size and shape measurements using backpropagation classifier. International Review on Computers and Software, 2010, 5(4): 489-494.

[24]. Alsmadi M K, Omar K B, Noah S A and Almarashdeh I. Fish recognition based on robust features extraction from color texture measurements using back-propagation classifier. Journal of Theoritical and Applied Information Technology, 2010, 18(1). 
[25]. Alsmadi M K, Omar K B, Noah S A and Almarashdeh I. Fish recognition based on robust features extraction from size and shape measurements using neural network. Journal of Computer Science, 2010, 6(10): 1088.

[26]. Almarashdeh I A, Sahari N, Zin N A M and Alsmadi M. Acceptance of learning management system: A comparison between distance learners and instructors. Advances in Information Sciences and Service Sciences, 2011, 3(5): 1-9.

[27]. ALMRASHDEH I A, SAHARI N, ZIN N A M and ALSMADI $M$. DISTANCE LEARNING MANAGEMENT SYSTEM REQIUREMENTS FROM STUDENT'S PERSPECTIVE. Journal of Theoretical \& Applied Information Technology, 2011, 24(1).

[28]. Almrashdeh I A, Sahari N, Zin N A M and Alsmadi M. Instructor's success measures of Learning Management System. In Electrical Engineering and Informatics (ICEEI), 2011 International Conference on, pp. 1-7.

[29]. Almrashdeh I A, Sahari N, Zin N A M and Alsmadi M. Requirement analysis for distance learning management system students in Malaysian universities. Journal of Theoretical and Applied Information Technology, 2011, 24(1): 17-27.

[30]. Alsmadi M, Omar K, Noah S and Almarashdeh I. A hybrid memetic algorithm with backpropagation classifier for fish classification based on robust features extraction from PLGF and shape measurements. Information Technology Journal, 2011, 10(5): 944-954.

[31]. Alsmadi M K, Omar K B and Noah S A. Fish classification based on robust features extraction from color signature using back-propagation classifier. Journal of Computer Science, 2011, 7(1): 52.

[32]. Alsmadi M, Omar K and Almarashdeh I. Fish Classification: Fish Classification Using
Memetic Algorithms with Back Propagation Classifier. 2012.

[33]. Alsmadi M, Badawi U A and Reffat H E. A High Performance Protocol for Fault Tolerant Distributed Shared Memory (FaTP). Journal of Applied Sciences, 2013, 13: 790-799.

[34]. Alsmadi M, Badawi U A, Reffat H E, Qiang S, Chanjian F, Yuegang $L$ and Peng S. Faults Diagnosis for Automotive Engine Based on Chinin. Journal of Applied Sciences, 2013, 13(23): 5632.

[35]. Badawi U A and Alsmadi M K S. A Hybrid Memetic Algorithm (Genetic Algorithm and Great Deluge Local Search) With BackPropagation Classifier for Fish Recognition International Journal of Computer Science Issues, 2013, 10(2): 348-356.

[36]. Thalji $\mathrm{Z}$ and Alsmadi M. Iris Recognition using robust algorithm for eyelid, eyelash and shadow avoiding. World Applied Sciences Journal, 2013, 25(6): 858-865.

[37]. Alsmadi M K. A hybrid firefly algorithm with fuzzy-C mean algorithm for MRI brain segmentation. American Journal of Applied Sciences, 2014, 11(9): 1676-1691.

[38]. Alsmadi M K, Badawi U A and Moharram H M. SERVER FAILURES ENABLED JAVASPACES SERVICE. Journal of Computer Science, 2014, 10(4): 671-679.

[39]. Badawi U A and Alsmadi M K. A GENERAL FISH CLASSIFICATION METHODOLOGY USING META-HEURISTIC ALGORITHM WITH BACK PROPAGATION CLASSIFIER. Journal of Theoretical \& Applied Information Technology, 2014, 66(3): 803-812.

[40]. Al Smadi A M, Alsmadi M K, Al Bazar H, Alrashed S and Al Smadi B S. Accessing Social Network Sites Using Work Smartphone for Face Recognition and Authentication. Research Journal of Applied Sciences, Engineering and Technology, 2015, 11(1): 56-62. 
[41]. Alsmadi M K. MRI brain segmentation using a hybrid artificial bee colony algorithm with fuzzy-c mean algorithm. Journal of Applied Sciences, 2015, 15(1): 100.

[42]. HADDAD F, ALFARO J and ALSMADI M K. HOTELLING'S $\mathrm{T}^{2} \quad$ CHARTS USING WINSORIZED MODIFIED ONE STEP MESTIMATOR FOR INDIVIDUAL NON NORMAL DATA. Journal of Theoretical \& Applied Information Technology, 2015, 72(2): 215-226.

[43]. Almarashdeh I and Alsmadi M. Investigating the acceptance of technology in distance learning program. In 2016 International Conference on Information Science and Communications Technologies (ICISCT), 2-4 Nov. 2016, pp. 1-5.

[44]. Almarashdeh I and Alsmadi M. Heuristic evaluation of mobile government portal services: An experts' review. In Internet Technology and Secured Transactions (ICITST), 2016 11th International Conference for, pp. 427-431.

[45]. Alsmadi M. Facial recognition under expression variations. Int. Arab J. Inf. Technol., 2016, 13(1A): 133-141.

[46]. Alsmadi M K. Forecasting River Flow in the USA Using a Hybrid Metaheuristic Algorithm with Back-Propagation Algorithm. Scientific Journal of King Faisal University (Basic and Applied Sciences), 2017, 18(1): 13-24.

[47]. Alsmadi M K. Query-sensitive similarity measure for content-based image retrieval using meta-heuristic algorithm. Journal of King Saud University - Computer and Information Sciences, 2017.

[48]. Alsmadi M K. An efficient similarity measure for content based image retrieval using memetic algorithm. Egyptian Journal of Basic and Applied Sciences, 2017, 4(2): 112-122.
[49]. Alsmadi M K and Badawi U A. Pattern matching in Rotated Images Using Genetic Algorithm. Journal of King Abdulaziz University Computing and Information 2017, 5: $53-59$.

[50]. Alsmadi M K, Hamed A Y, Badawi U A, Almarashdeh I, Salah A, Farag T H, Hassan W, Jaradat G, Alomari Y M and Alsmadi H M. FACE IMAGE RECOGNITION BASED ON PARTIAL FACE MATCHING USING GENETIC ALGORITHM. SUST Journal of Engineering and Computer Sciences (JECS), 2017, 18(1): 51-61.

[51]. Farag T H, Hassan W A, Ayad H A, AlBahussain A S, Badawi U A and Alsmadi M K. Extended Absolute Fuzzy Connectedness Segmentation Algorithm Utilizing Region and BoundaryBased Information. Arabian Journal for Science and Engineering, 2017: 1-11.

[52]. Aldaej R, Alfowzan L, Alhashem R, Alsmadi M K, Al-Marashdeh I, Badawi U A, Alshabanah M, Alrajhi D and Tayfour M. Analyzing, Designing and Implementing a Web-Based Auction online System. International Journal of Applied Engineering Research, 2018, 13(10): 8005-8013.

[53]. Almaimoni H, Altuwaijri N, Asiry F, Aldossary S, Alsmadi M, Al-Marashdeh I, Badawi U A, Alshabanah $\mathrm{M}$ and Alrajhi D. Developing and Implementing WEB-based Online Destination Information Management System for Tourism. International Journal of Applied Engineering Research, 2018, 13(10): 7541-7550.

[54]. Almarashdeh i, Alsmadi M K, Farag T, Albahussain A S, Badawi U A, Altuwaijri N, Almaimoni H, Asiry F, Alowaid S, Alshabanah M, Alrajhi D, Fraihet A A and Jaradat G. RealTime Elderly Healthcare Monitoring Expert System Using Wireless Sensor Network International Journal of Applied Engineering Research, 2018, 13(6): 3517-3523. 
[55]. Almarashdeh I, Alsmadi M K, Jaradat G, Althunibat A, Albahussain S A, Qawqzeh Y, Badawi U A, Farag T and Eldaw K E. Looking Inside and Outside the System: Examining the Factors Influencing Distance Learners Satisfaction in Learning Management System Journal of Computer Science, 2018.

[56]. Almarashdeh I, Eldaw K E, AlSmadi M, Badawi U, Haddad F, Abdelkader O A, Jaradat G, Alkhaldi A and Qawqzeh Y. Search Convenience and Access Convenience: The Difference Between Website Shopping and Mobile Shopping. In International Conference on Soft Computing and Pattern Recognition, pp. 33-42.

[57]. Al-Marashdeh I, Jaradat G M, Ayob M, Abu-AlAish A and Alsmadi M. An Elite Pool-Based Big Bang-Big Crunch Metaheuristic for Data Clustering. Journal of Computer Science, 2018, 14(12): 1611-1626.

[58]. Alsmadi M K. Apparatus and method for lesions segmentation. 2018.

[59]. Alsmadi M K. Facial expression recognition. 2018.

[60]. Alsmadi M K. A hybrid Fuzzy C-Means and Neutrosophic for jaw lesions segmentation. Ain Shams Engineering Journal, 2018, 9(4): 697-706.

[61]. Alsmadi M K. Query-sensitive similarity measure for content-based image retrieval using meta-heuristic algorithm. Journal of King Saud University-Computer and Information Sciences, 2018, 30(3): 373-381.

[62]. Alsubaie N, Althaqafi N, Alradwan E, Al-Hazza F, Alsmadi M, Al-Marashdeh I, Badawi U A, Alshabanah M, Alrajhi D, Alsmadi S and Tayfour M. Analyzing and Implementing an Online Metro Reservation System. International Journal of Applied Engineering Research, 2018, 13(11): 9198-9206.

[63]. Daniyah Alkhaldi D A, Hajer Aldossary, Mutasem k. Alsmadi, Ibrahim Al-Marashdeh,
Usama A Badawi, Muneerah Alshabanah, Daniah Alrajhi. Developing and Implementing Web-based Online University Facilities Reservation System. International Journal of Applied Engineering Research, 2018, 13(9): 6700-6708.

[64]. Haddad F and Alsmadi M K. Improvement of The Hotelling's T2 Charts Using Robust Location Winsorized One Step M-Estimator (WMOM). Journal of Mathematics (ISSN 10162526), 2018, 50(1): 97-112.

[65]. Rasmi M, Alazzam M B, Alsmadi M K, Almarashdeh I A, Alkhasawneh R A and Alsmadi S. Healthcare professionals' acceptance Electronic Health Records system: Critical literature review (Jordan case study). International Journal of Healthcare Management, 2018: 1-13.

[66]. Abbas A A, Alzayer K, Alkhaldi A, Alsmadi M k, Alshabanah M, Alrajhi D, Almarashdeh I and Tayfour M. Analyzing and Implementinga System For Reporting, Follow Up and Resolving of Complaints. International Research Journal of Engineering and Technology, 2019, 6(1): 1833-1842.

[67]. Ahmed A O, Ahmed M E, Mekebbaty M M E, Osman A M, Mohamed A S, Alhaj G M and Shidwan O S. Impact of Change Characteristics in Planning for Future Professional Career. International Journal of Applied Engineering Research, 2019, 14(20): 3869-3878.

[68]. Aldossary S, Althawadi A, Almotairy M, Alsmadi M k, Alrajhi D, Alshabanah M, AlMarashdeh I, Tayfour M and Aljamaeen R. ANALYZING, DESIGNING AND IMPLEMENTING A WEB-BASED COMMAND CENTER SYSTEM. International Research Journal of Engineering and Technology, 2019, 6(1): 1008-1019.

[69]. Al-Ghamdi A, Al Harbi D, Alarfaj N, Al Hajri A, Almarashdeh I, Alsmadi M, Alshabanah $\mathrm{M}$ and 
Alrajhi D. Developing and Implementing a Web-Based Platform for Skills and Knowledge Exchange. Int J Sci Res Sci Technol, 2019, 6(3): 562-573.

[70]. Al-Ghamdi A, Harbi D A, Alarfaj N, Hajri B A, Almarashdeh I, Alsmadi M k, Alshabanah M and Alrajhi D. Developing and Implementing a Web-Based Platform for Skills and Knowledge Exchange. International Journal of Scientific Research in Science and Technology (IJSRST), 2019, 6(3).

[71]. Alhafi R, Almutairi S, Alsultan N, Alsmadi M K, Alshabanah M, Alrajhi D and Almarashdeh I. EPayment and Transactions using QR Codes. 2019.

[72]. Alharbi S, Altamimi A, Al-Qahtani F, Aljofi B, Alsmadi M, Alshabanah M, Alrajhi D and Almarashdeh I. Analyzing and Implementing a Mobile Reminder System for Alzheimer's Patients. International Research Journal of Engineering and Technology, 2019, 6(2): 1-11.

[73]. Ali S A S, Eldaw K E H I, Alsmadi M K and Almarashdeh I. Determinants of deposit of commercial banks in Sudan: an empirical investigation (1970-2012). International Journal of Electronic Finance, 2019, 9(3): 230-255.

[74]. Almarashdeh I, Jaradat G, Abuhamdah A, Alsmadi M, Alazzam M B, Alkhasawneh R and Awawdeh I. The Difference Between Shopping Online Using Mobile Apps and Website Shopping: A Case Study of Service Convenience. International Journal of Computer Information Systems and Industrial Management Applications, 2019, 11: 151-160.

[75]. Al-Omairi D S, AlNasheri W H, Al-Qarni W Y, Almarashdeh I, Alsmadi M k, Alshabanah M and Alrajhi D. Developing and Implementing A Web-Based Recycling System For Protecting The Green Environment. International Journal of Software Engineering and Applications, 2019, 10(3): 59-72.
[76]. Alomari E, Alshammry M, Alhamil S, Alsmadi M, Alshabanah M, Alrajhi D, Almarashdeh I and Eljawad L. Analyzing, Designing and Implementing a Consulting Company for Management Information Systems. International Research Journal of Engineering and Technology, 2019, 6(2): 422-432.

[77]. Alomari E, Alshammry M, Alhamil S, Alsmadi M k, Alshabanah M, Alrajhi D, Almarashdeh I and Eljawad L. Analyzing, Designing and Implementing a Consulting Company for Management Information Systems. International Research Journal of Engineering and Technology 2019, 6(2): 422-432.

[78]. Al-Smadi A M, Alsmadi M K, Baareh A, Almarashdeh I, Abouelmagd $\mathrm{H}$ and Ahmed O S S. Emergent situations for smart cities: a survey. International Journal of Electrical \& Computer Engineering (2088-8708), 2019, 9(6): 4777-4787.

[79]. Alsmadi M K. Hybrid Genetic Algorithm with Tabu Search with Back-Propagation Algorithm for Fish Classification: Determining the Appropriate Feature Set. International Journal of Applied Engineering Research, 2019, 14(23): 4387-4396.

[80]. Alsmadi M K, Tayfour M, Alkhasawneh R A, Badawi U, Almarashdeh I and Haddad F. Robust feature extraction methods for general fish classification. International Journal of Electrical \& Computer Engineering (2088-8708), 2019, 9(6): 5192-5204.

[81]. Al-Theeb R, Al-Tami H, Al-Johani H, AlMutairi A, Al-Marashdeh I, Alsmadi M K, Alshabanah $\mathrm{M}$ and Alrajhi D. Developing and Implementing A System for Shipping Companies Comparison. IJSRST 2019, 6(4).

[82]. Alzamel H, Alshabanah $\mathrm{M}$ and Alsmadi $\mathrm{M}$. Point of Sale (POS) Network with Embedded Fingerprint Biometric Authentication. International Journal of Scientific Research in 
Science and Technology (IJSRST), 2019, 6(5): 95-111.

[83]. Eljawad L, Aljamaeen R, Alsmadi M K, AlMarashdeh I, Abouelmagd H, Alsmadi S, Haddad F, Alkhasawneh R A, Alzughoul M and Alazzam M B. Arabic Voice Recognition Using Fuzzy Logic and Neural Network. International Journal of Applied Engineering Research, 2019, 14(3): 651-662.

[84]. Haddad F, Alsmadi M K, Badawi U, Farag T, Alkhasawneh R, Almarashdeh I and Hassan W. Bivariate modified hotelling's $\mathrm{T}^{2}$ charts using bootstrap data. International Journal of Electrical \& Computer Engineering (20888708), 2019, 9(6): 4721-4727.

[85]. Mohammed A S S, Alhaj G M, Osman A M and Ahmed A O. The Effectiveness of the Decision Making of the Saudi Arabian Universities Applied Colleges' Faculties Boards and Departmental Councils. International Journal of Applied Engineering Research, 2019, 14(23): 4221-4227.

[86]. Osman A M, Ahmed A O, Eltahir M N, Mohamed A S, Shidwan O S and Ghada M. Investigating the Causes of inflation in Saudi Arabia: An Application of Autoregressive Distributed Lag (ARDL) Model. International Journal of Applied Engineering Research, 2019, 14(21): 3980-3986.

[87]. Qawqzeh Y K, Otoom M M, Al-Fayez F, Almarashdeh I, Alsmadi M and Jaradat G. A Proposed Decision Tree Classifier for Atherosclerosis Prediction and Classification. IJCSNS, 2019, 19(12): 197.

[88]. Sheikh R A, Al-Assami R, Albahr M, Suhaibani M A, Alsmadi M k, Alshabanah M, Alrajhi D, Al-Marashdeh I, Alsmadi S, Abouelmagd $\mathrm{H}$ and Tayfour M. Developing and Implementing a Barcode Based Student Attendance System. International Research Journal of Engineering and Technology, 2019, 6(1): 497-506.
[89]. Alsmadi M K. Content-Based Image Retrieval Using Color, Shape and Texture Descriptors and Features. Arabian Journal for Science and Engineering, 2020: 1-14.

[90]. Alzaqebah M A, Alrefai N, Ahmed E, Jawarneh $S$ and Alsmadi M. Neighborhood search methods with Moth Optimization algorithm as a wrapper method for feature selection problems. International Journal of Electrical \& Computer Engineering, 2020, 10(4).

[91]. Qawqzeh Y K, Jaradat G, AlYousef A, AbuHamdah A, Almarashdeh I, Alsmadi M, Tayfour M, Shaker K and Haddad F. Applying the Big Bang-Big Crunch Metaheuristic to Large-sized Operational Problems. International Journal of Electrical and Computer Engineering, 2020, 10(3): 2484-2502.

[92]. Adeyemo J, Oyebode O and Stretch D. River Flow Forecasting Using an Improved Artificial Neural Network. EVOLVE-A Bridge between Probability, Set Oriented Numerics, and Evolutionary Computation VI. Springer, 2018, pp. 179-193.

[93]. Ahani A, Shourian $M$ and $\operatorname{Rad} P \quad R$. Performance Assessment of the Linear, Nonlinear and Nonparametric Data Driven Models in River Flow Forecasting. Water Resources Management, 2018: 1-17.

[94]. Alsmadi M K. A hybrid Fuzzy C-Means and Neutrosophic for jaw lesions segmentation. Ain Shams Engineering Journal.

[95]. M A, K O and S N. Back Propagation Algorithm : The Best Algorithm Among the Multi-layer Perceptron Algorithm. International Journal of Computer Science and Network Security, 2009, 9(9): 378-383.

[96]. Alsmadi M k, Omar K B, Noah S A and Almarashdah I. Performance Comparison of Multi-layer Perceptron (Back Propagation, Delta Rule and Perceptron) algorithms in Neural Networks. In 2009 IEEE International 
Advance Computing Conference, 6-7 March 2009, pp. 296-299.

[97]. Sharma M, Purohit G and Mukherjee S. Information Retrieves from Brain MRI Images for Tumor Detection Using Hybrid Technique K-means and Artificial Neural Network (KMANN). Networking Communication and Data Knowledge Engineering. Springer, 2018, pp. 145-157.

[98]. Gao Y, Li X, Dong M and Li H-p. An enhanced artificial bee colony optimizer and its application to multi-level threshold image segmentation. Journal of Central South University, 2018, 25(1): 107-120.

[99]. Alsmadi M K. A hybrid Fuzzy C-Means and Neutrosophic for jaw lesions segmentation. Ain Shams Engineering Journal, 2017.

[100].Park S H and Han K. Methodologic Guide for Evaluating Clinical Performance and Effect of Artificial Intelligence Technology for Medical Diagnosis and Prediction. Radiology, 2018: 171920.

[101].Kermany D S, Goldbaum M, Cai W, Valentim C C, Liang H, Baxter S L, McKeown A, Yang G, $\mathrm{Wu} \mathrm{X}$ and Yan F. Identifying Medical Diagnoses and Treatable Diseases by Image-Based Deep Learning. Cell, 2018, 172(5): 1122-1131. e1129.

[102].Alsmadi M, Omar K B, Noah S A and Almarashdeh I. Fish Recognition Based on Robust Features Extraction from Size and Shape Measurements Using Neural Network Journal of Computer Science, 2010, 6(10): 1088-1094.

[103].Alsmadi M K. An efficient similarity measure for content based image retrieval using memetic algorithm. Egyptian Journal of Basic and Applied Sciences.

[104].Alsmadi M K. Query-sensitive similarity measure for content-based image retrieval using meta-heuristic algorithm. Journal of King Saud University - Computer and Information Sciences.
[105].Yousuf M, Mehmood Z, Habib H A, Mahmood T, Saba T, Rehman A and Rashid M. A Novel Technique Based on Visual Words Fusion Analysis of Sparse Features for Effective Content-Based Image Retrieval. Mathematical Problems in Engineering, 2018, 2018.

[106].Saritha R R, Paul V and Kumar P G. Content based image retrieval using deep learning process. Cluster Computing, 2018: 1-14.

[107].Jaradat G M, Al-Badareen A, Ayob M, Al-Smadi M, Al-Marashdeh I, Ash-Shuqran M and AlOdat E. Hybrid Elitist-Ant System for NurseRostering Problem. Journal of King Saud University-Computer and Information Sciences, 2018.

[108].Nabiyev V, Karal H, Arslan S, ERUMIT A K and Ayça C. An artificial intelligence-based distance education system: Artimat. Turkish Online Journal of Distance Education, 2013, 14(2).

[109].Cavus N. The evaluation of Learning Management Systems using an artificial intelligence fuzzy logic algorithm. Advances in Engineering Software, 2010, 41(2): 248-254.

[110].Wakelam E, Jefferies A, Davey N and Sun Y. The potential for using artificial intelligence techniques to improve e-Learning systems. In European Conference on e-Learning, pp. 762.

[111].Sivakumar S, Venkataraman S and Gombiro C. A user-intelligent adaptive learning model for learning management system using data mining and artificial intelligence. 2015.

[112].Gomede E, Gaffo F H, Briganó G U, de Barros R $\mathrm{M}$ and Mendes L d S. Application of Computational Intelligence to Improve Education in Smart Cities. Sensors, 2018, 18(1): 267.

[113].Faraj A, Alzahrani S, Almumtin R, Alrajhi D, Alshyban S, Alshabanah M, Alsmadi $\mathrm{M}$ and Almarashdeh I. Developing and Implementing an Online Learning Platform for Children with 
Autism. International Journal of Scientific Research in Science and Technology, 2020.

[114].Alqarni N, Alqahtani S, Alhumaidi S A, Almutairi I, Alshabanah M, Alrajhi D, Alsmadi $\mathrm{M}$ and Almarashdeh I. Developing a Platform for Chronic Diseases Awareness. International Journal of Scientific Research in Science and Technology, 2020.

[115].Alqahtani M, Bashunaym R, Alotaibi N, Alkhaldi R, Alshabanah M, Alrajhi D, Alsmadi $\mathrm{M}$ and Almarashdeh I. Developing a Smart Nursery Application for Monitoring and Babies Care. International Journal of Scientific Research in Science and Technology, 2020.

[116].Alqahtani A, Alshehri B, Alqahtani M, Abumelha M, Alshabanah M, Alrajhi D, Alsmadi $\mathrm{M}$ and Almarashdeh I. Developing and Implementing a Website for Sports Clubs. International Journal of Scientific Research in Science and Technology (IJSRST), 2020, 7(2): 135-146.

[117].Alkhalfan A S, Altheeb Z W, Alshamsi N A, Alothman H W, Almarashdeh I, Alshabanah M, Alrajhi D and Alsmadi M. Designing and Developing of E-Commerce Website for Unused New Goods Shopping. International Journal of Scientific Research in Science and Technology (IJSRST), 2020, 7(2): 215-225.

[118].Al Hayek F, Khelaif M, Shaikh Z, Alshammari $\mathrm{H}$, Alshabanah $\mathrm{M}$, Alrajhi D, Alsmadi $\mathrm{M}$ and Almarashdeh I. Developing and Implementing a Web-Based educational platform for Children with Special Needs. International Journal of Scientific Research in Science and Technology, 2020.

[119].Al-Omairi D, AlNasheri W, Al-Qarni W, Almarashdeh I, Alsmadi M, Alshabanah M and Alrajhi D. Developing and Implementing a Web-Based Recycling System for Protecting the Green Environment. International Journal of
Software Engineering \& Applications (IJSEA), 2019, 10(3).

[120].Alhafi R, Almutairi S, Alsultan N, Alsmadi M K, Alshabanah M, Alrajhi D and Almarashdeh I. EPayment and Transactions using QR Codes. International Research Journal of Engineering and Technology, 2019, 6(2): 433-443.

\section{Cite this article as :}

Noora Yousef A Alomran, Amani Osama M Alameer, Maryam Sami K Alherz, Mohammed Fahed Tayfour, Muneerah Alshabanah, Daniah Alrajhi, Mutasem K. Alsmadi , "Developing an Effective e-Learning Platform", International Journal of Scientific Research in Science and Technology (IJSRST), Online ISSN : 2395-602X, Print ISSN : 2395-6011, Volume 7 Issue 3, pp. 249-261, May-June 2020. Available at doi : https://doi.org/10.32628/IJSRST207336

Journal URL : http://ijsrst.com/IJSRST207336 